\title{
A GLOBAL MICROARRAY EXPRESSION PROFILE OF GRAPEVINE MIRNAS ISOLATED FROM CELL SUSPENSIONS PRE-TREATED WITH APOPTOSIS ACTIVATORS
}

\author{
VLADIMÍR REPKA', MÁRIA ČARNÁ2,3 \\ ${ }^{1}$ Plant Production Research Center Piešt'any \\ ${ }^{2}$ Institute of Botany, Slovak Academy of Sciences, Bratislava \\ ${ }^{3}$ Slovak University of Technology, Bratislava
}

REPKA, V. - ČARNÁ, M.: A global microarray expression profile of grapevine miRNAs isolated from cell suspensions pre-treated with apoptosis activators. Agriculture (Pol'nohospodárstvo), vol. 58, 2012, no. 1, pp. 11-17.

In an attempt to identify novel and apoptosis/pathogenregulated microRNAs (miRNAs) and small interfering RNAs, we performed a robust microarray screening of small RNA population from Vitis vinifera L. cv. Limberger cell suspension exposed to apoptosis activators (e.g. methyl jasmonate) or elicitors (botrycin and cinerein) derived from necrotrophic fungus Botrytis cinerea Pers. et Fries. Using a microarray expression profiling approach, we identified 22 miRNAs. We found that a majority of these miRNAs were predicted to target stress/defense-related genes of plants. Of the $22 \mathrm{~V}$. vinifera miRNAs, 11 have sequence conservation in Arabidopsis thaliana but exhibited species-specific developmental and/or stress/defense-related expression patterns. Ten of the miRNAs are highly conserved in other plant species, suggesting that even conserved miRNAs may have different regulatory roles in various species. Our results show that these grapevine miRNAs can be also induced by various apoptosis inducers. Fifty-one potential targets were predicted to the newly identified miRNAs based on sequence complementarity. In addition to miRNAs, we identified 102 other novel endogenous small RNAs in Vitis, indicating that a large number of miRNAs and other small regulatory RNAs are encoded by the Vitis vinifera genome.

Key words: Vitis vinifera L., small RNA, cell death, elicitor, methyl jasmonate

In higher plants, programmed cell death (PCD), which distinguishes from necrosis resulting from severe injury caused by a plethora of external events, plays a vital role in proper biogenesis and morphogenesis. Similar to apoptosis in animal cells, some biotic or abiotic stimuli trigger the death pathway, resulting in mitochondrial dysfunction, generation of reactive oxygen species (ROS), activation of specific proteases and fragmentation of DNA. Some features of plant PCD, including hypersensitive reaction (HR), resemble the apoptotic process. Thus in plant PCD, caspase-like protease activity is observed during tobacco mosaic virus induced HR (Chichkova et al. 2004) or jasmonate (JA) induced cell death (Repka 2002). Vacuolar processing enzyme has caspase-1 activity and mediates tobacco mosaic virus induced HR in tobacco (Hatsugai et al. 2004; Hara-Nishimura et al. 2005). Overexpression of the transcription factor AmMYB308 in transgenic tobacco inhibits the metabolism of phenolic acid, which leads to precocious cell death in mature leaves due to an increase in the concentration of ROS. In the maize mutant Les22, impairment of the porphyrin biosynthesis pathway results in accumulation of uroporphyrin, which triggers the production of cell-damaging ROS. Impaired fatty acid biosynthesis in an Arabidopsis modl (mosaic death 1) mutant caused dramatic alter-

RNDr. Vladimír Repka, CSc., Plant Production Research Center Piešt’any - Research Institute of Viticulture and Enology, Bratislava 833 11, Matúšková 25, Slovak Republic. E-mail: mysteriousman@szm.sk

Ing. Mária Čarná, Institute of Botany, Slovak Academy of Sciences, 84523 Bratislava, Dúbravská cesta 9, Slovak University of Technology, Radlinského 9, Bratislava 812 37, Slovak Republic. E-mail: maria.carna@stuba.sk 
ations in plant morphology and premature cell death. In addition, mammalian Bax is capable of inducing cell death in yeast (Zha et al. 1996) and also in plant cells (Lacomme \& Cruz 1999). Such evidence suggests the existence of a common mechanism for animal and plant cell death pathways.

Our previous results clearly demonstrated that JAs play an important role in induction of apoptosis in grapevine cells and the same mechanism may be involved as a part of a strategy of the necrotrophic pathogens biology (Repka et al. 2001; Repka 2002). In spite of the importance of JAs as stress and growth regulators being well recognised, relatively little is known about the molecular mechanisms governing methyl JA (MeJA) perception and subsequent signalling events that lead to activation of downstream MeJA-responsive genes. Conventional forward genetic screens for JA-resistant (insensitive) mutants have led to the identification of a few molecular players in the JA/MeJAsignalling network, including ubiquitin-mediated proteolysis machinery. Unfortunately, extensive conventional forward genetic screens failed to identify the JA receptor(s). With this in mind, an alternative approach that may complement the limitations of conventional genetics to further dissect JA signalling must be looked for. First, so-called "chemical genetics" is a powerful approach to dissect biological processes that may be intractable using conventional genetics because of gene function redundancy or lethality.

Alternatively, in plants and animals various stimuli trigger rapid changes in transcript levels, including down-regulation of a gene subset, potentially by posttranscriptional mechanisms. One post-transcriptional mechanism is RNA silencing, a sequence-specific mRNA degradation process mediated by 20-24 nucleotide RNAs known as microRNAs (miRNAs). Mature miRNAs are generated through multiple processing steps from primary pri-miRNA transcripts that contain imperfect foldback structures.

The miRNAs affect morphology of the flowering plant by posttranscriptional regulation of genes involved in the critical developmental events. With respect to apoptosis and/or PCD, there are only a few reports regarding the use of miRNA inhibitors in functional screening assays to identify miRNAs that affect this process (Brennecke et al. 2008; Repka \& Baumgartnerová 2008). In our contribution, we examined whether small RNAs, especially miRNAs, contribute to the rapid changes elicited by MeJA and other apoptosis activators. We also used screening to identify miRNAs involved in induction or inhibition of steady state levels of apoptosis in grapevine cells and correlated them with the mechanism of resistance induced to necrotrophic pathogens.

\section{MATERIAL AND METHODS}

\section{Plant material}

Long-term cultivated callus cultures of grapevine (Vitis vinifera L., cv. Limberger) were used for all the experiments. These cultures were established and maintained basically according to Repka et al. (2000).

\section{Elicitor preparation and cells pre-treatment}

A necrotroph pathogen Botrytis cinerea Pers. et Fries (a grapevine stock isolate) was cultivated on potato dextrose agar (Oxoid Ltd., London, UK) in the dark at $25^{\circ} \mathrm{C}$. The fungal cell wall (botrycin) and the extracellular (cinerein) elicitor were prepared from cultivated necrotroph according to the protocols published elsewhere (Repka et al. 2001; Repka 2002).

A stock solution $(5 \mathrm{mM})$ of MeJA (Duchefa BV, Haarlem, The Netherlands) was first made up in absolute ethanol; various concentration of MeJA $(0.05-50 \mu \mathrm{M})$ were prepared by appropriate dilution in water and adjusted to the final concentration with $0.1 \%$ ethanol. A commercial grade of hydrogen peroxide $\left(\mathrm{H}_{2} \mathrm{O}_{2}\right)$ diluted with sterile distilled water was also used as the elicitor.

Grapevine cell suspensions were incubated with respective elicitors at various range of concentrations and $0.1 \%$ ethanol or sterile distilled water was applied as control. After the pre-treatment was completed, cells were harvested and immediately submerged in RNAlater ${ }^{\mathrm{TM}}$ solution (Ambion, Austin, TX, USA) for archival storage at $-20^{\circ} \mathrm{C}$.

\section{Microscopy and cytochemistry}

Cell viability was determined cytochemically by staining of cells with a solution containing fluorescein diacetate and propidium iodide (PI) in sterile 24-well tissue culture plates (Nunc AS, Roskilde, Denmark) as described previously (Repka et al. 2001). The integrity of DNA in nucleus of control and treated cells was estimated with 4',6-diamidino-2-phenylindole staining (Repka et al. 2001). Cytochemically-stained cells were 
observed under a LEICA DMIRB fluorescence microscope equipped with a LEICA DC 450 colour CCD camera (Leica, Wetzlar, Germany). Digital images were processed with Adobe Photoshop CS3 software (Adobe, San José, CA, USA).

\section{Isolation of total RNA}

An aliquot (1 mg FW-fresh weight) from each, control (untreated) and elicitor-treated cells was immediately placed in sterile Eppendorf microtubes containing RNAlater ${ }^{\mathrm{TM}}$ solution (Ambion, Austin, TX, USA) for storage until RNA extraction was performed. Total RNA was extracted from the cells using the mirVana ${ }^{\mathrm{TM}}$ miRNA Isolation Kit (Ambion, Austin, TX, USA) according to the manufacturer's protocol. Using a Nanodrop ND-1000 (Nanodrop Technologies, Willmington, DE, USA), the total RNA was assessed for quality and quantity and then stored at $-80^{\circ} \mathrm{C}$ until future use.

\section{Microarray expression profiling}

A high throughput screening and expression profiling of miRNAs prepared from control, elicitor- and MeJA-treated cell suspensions were performed on Plant miRNA One Array ${ }^{\mathrm{TM}}$ microarrays (Phalanx Biotech Group, Belmont, CA, USA) containing 100\% Sanger miRBase v11. A single-stranded miRNA cDNA for each of the miRNAs was prepared using the procedure described in methodology of quantitative reverse transcription polymerase chain reaction (qRT-PCR). The cDNA $(10 \mu \mathrm{g})$ was hybridised to One Array ${ }^{\mathrm{TM}}$ microarray. The array was incubated for $18 \mathrm{~h}$ and then automatically washed and stained with One Array ${ }^{\mathrm{TM}}$ hybridisation, wash and stain kit (Phalanx). The plant microarrays were scanned using an InnoScan 700 dual fluorescence scanner (Innopsys, Carbonne, France).

\section{Data analysis and bioinformatics}

Expression analysis was performed using Mapix V. 4.0.0 software (Innopsys) and miRNAs were defined as responsive when transcripts were detected in at least two of the three independent experiments (biological replicates) and when the signals were significantly different $(P \leq 0.05)$ as compared with the control cells. Data mining, hierarchical clustering and visualisation were performed using Cluster and TreeView software (Eisen et al. 1998; see http://rana.lbl.gov/). The permutation t-test (Hedenfalk et al. 2001) was calculated using the program Cluster Identification Tool (Taka- hashi et al. 2001). The BLAST and the BLASTn database searches were exactly performed using NCBIBLASTN engine with a Wordsize of 4 (Altschul et al. 1997).

\section{Quantitative real-time PCR}

TaqMan $^{\mathrm{TM}}$ miRNA assay (Applied Biosystems, Foster City, CA, USA) was used to verify the expression of 22 identified grapevine miRNAs. First, (RT-PCR) was performed using the TaqMan ${ }^{\mathrm{TM}}$ miRNA reverse transcription kit (Applied Biosystems) and miRNAspecific stem-loop primers included in the kit. Briefly, $1 \mu \mathrm{g}$ of total grapevine RNA was used to generate a single-stranded miRNA cDNA for each of the miRNAs listed in the text. RT-PCR conditions were followed according to the manufacturer's protocol supplied with the kit. Second, qRT-PCR and miRNA specific primers were used to verify the expression of identified grapevine miRNAs. The reactions were run on an Eppendorf Mastercycler $^{\mathrm{TM}}$ ep realplex ${ }^{2}$ qRT-PCR cycler (Eppendorf, Hamburg, Germany). Three biological replicates along with two technique replicates were conducted for each miRNA. Following qRT-PCR, differences in miRNA expression levels were assessed by analysing the mean $C_{\mathrm{T}}$ (threshold cycle) values.

\section{Northern blotting}

For Northern blot analysis, aliquots containing $5 \mu \mathrm{g}$ of total RNA were denatured in $2.5 \mathrm{M}$ formaldehyde, $6 \times \operatorname{SSPE}\left(6 \times \mathrm{SSPE}=900 \mathrm{mM} \mathrm{NaCl}, 60 \mathrm{mM} \mathrm{NaH}_{2} \mathrm{PO}_{4}\right.$, $6 \mathrm{mM}$ ethylenediaminetetracetic acid, $\mathrm{pH} \mathrm{7.7)}$ at $60^{\circ} \mathrm{C}$ for $1 \mathrm{~h}$, fractionated on a $1.2 \%$ formaldehyde gel and transferred to a nylon membrane (NYTRAN N-13, Schleicher \& Schuell, Dassel, Germany). The membrane was washed, prehybridised and hybridised according to Repka et al. (2004).

Custom-made, gene-specific synthetic oligonucleotide probes (MWG Biotech GmbH., Ebersberg, Germany), end-labelled with biotin were used. Hybridisation of the probes, post-hybridisation stringency washes and membrane blocking with BLOTTO$M F$ solution was performed following the previously published protocols (Repka et al. 2004). Membranes were then incubated in a solution containing a horseradish peroxidase-conjugated avidin D (Vector Labs., Burlingame, NJ, USA) in tris-buffered saline for $1 \mathrm{~h}$. Finally, the membranes were washed in tris-buffered saline and the signal was visualised using SuperSignal West Dura (Pierce, Rockford, USA) and enhanced 
chemiluminiscence images were recorded on the Kodak Image Station 2000R (Kodak, Hemel Hempstead, UK).

\section{RESULTS AND DISCUSSION}

Pre-treatment of grapevine cell suspension with $50 \mu \mathrm{M}$ MeJA resulted in a progressive cell death by a time dependent manner (Figure 1, column "Visible"). Cytochemical observation of treated suspensions by double labeling with FITC/PI clearly demonstrated that cells die alongside the temporal axis (Figure 1, column "FITC/PI") and is accompanied by DNA fragmentation to oligonucleosomal fragments (Figure 1, column "DAPI").

In this study, a microarray suitable for the detection of grapevine miRNAs is described. A similar methodology was effectively used to detect miRNAs in prostate cancer cells (Tang et al. 2011), miRNA expression profiling of tomato leaf curl New Delhi virus (tolcndv) infected tomato leaves (Naqvi et al.
2011) or genome-wide functional characterisation of drought stress responsive miRNAs in Populus euphratica (Li et al. 2011). Microarray-based analysis of cadmium-responsive miRNAs in rice (Ding et al. 2011) and virus-infected tomato miRNAs (Lang et al. 2011) was also recently demonstrated.

In our assay, a total of 808 unique miRNA probes and 26 unique experimental control probes were spotted on a microarray. Using this platform, the overall miRNA expression profile within the cell suspension was clearly determined (Figure 2A). Microarray analysis showed that the expression of 22 miRNA genes was significantly upregulated when the grapevine cells were pre-treated with respective apoptosis activators. A graphical representation of array values organised by hierarchical clustering of the experiment is shown in Figure 2B and demonstrated differential expression profiles of five clusters of grapevine miRNAs depending on elicitor used. Recent evidence has shown that polycistronic miRNAs, or several different mature miRNAs derived from the same primary miRNA transcripts, exist in plants (Merchan et al. 2009). Evidence of miRNA

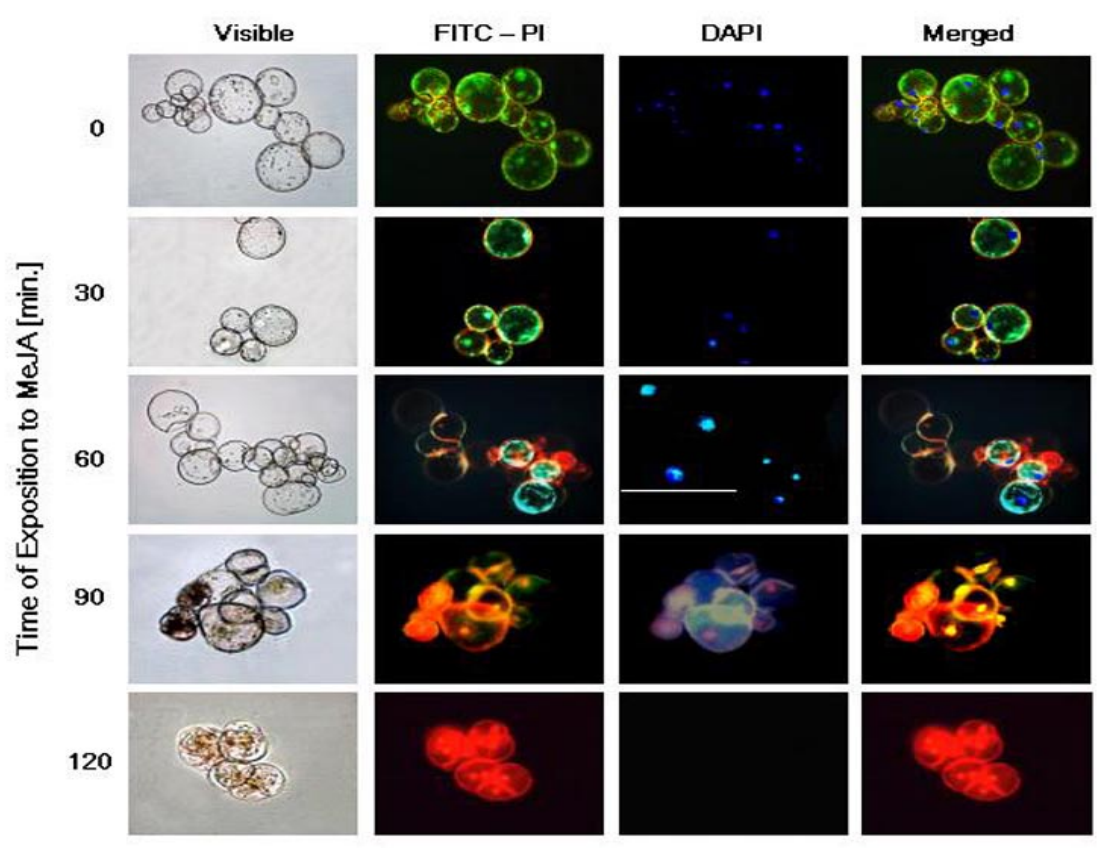

Figure 1. Temporal cytochemical analysis of grapevine cell suspension undergoing programmed cell death (apoptosis) triggered by exposition of cells to $50 \mu \mathrm{M}$ MeJA. Bar represents $100 \mu \mathrm{m}$. (PI: propidium iodide, DAPI: 4',6-diamidino-2phenylindole) 
clusters has also been reported in several plant species including Arabidopsis (Jones-Rhoades \& Bartel 2004), moss (Talmor-Neiman et al. 2006), cotton (Zhang et al. 2007) and soybean (Zhang et al. 2008).
To test the overall variability between individual microarray experiments, raw signal intensities from individual pre-treatments were plotted against untreated control set. Scatter plots of the raw data in Figure

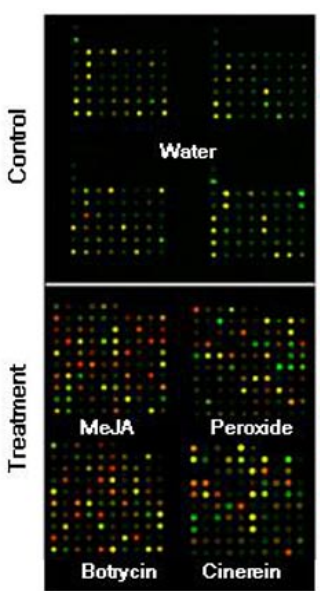

A

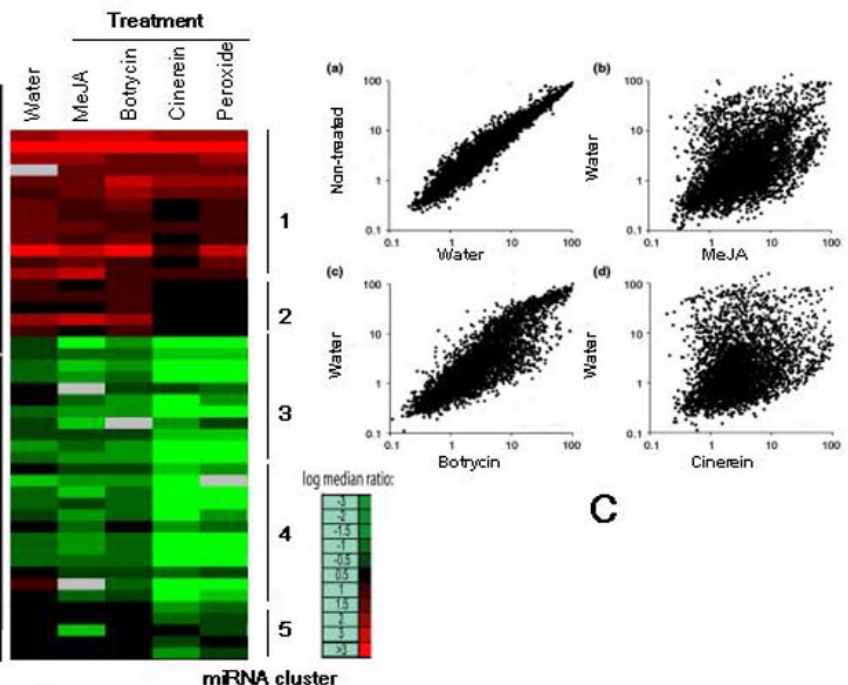

B

Figure 2. A global microarray expression profile of grapevine miRNAs isolated from grapevine cell suspensions pre-treated with different apoptosis activators. Microarray platform visualization (A), heat maps and miRNA expression cluster identification (B) and corresponding Scatter plots (C)

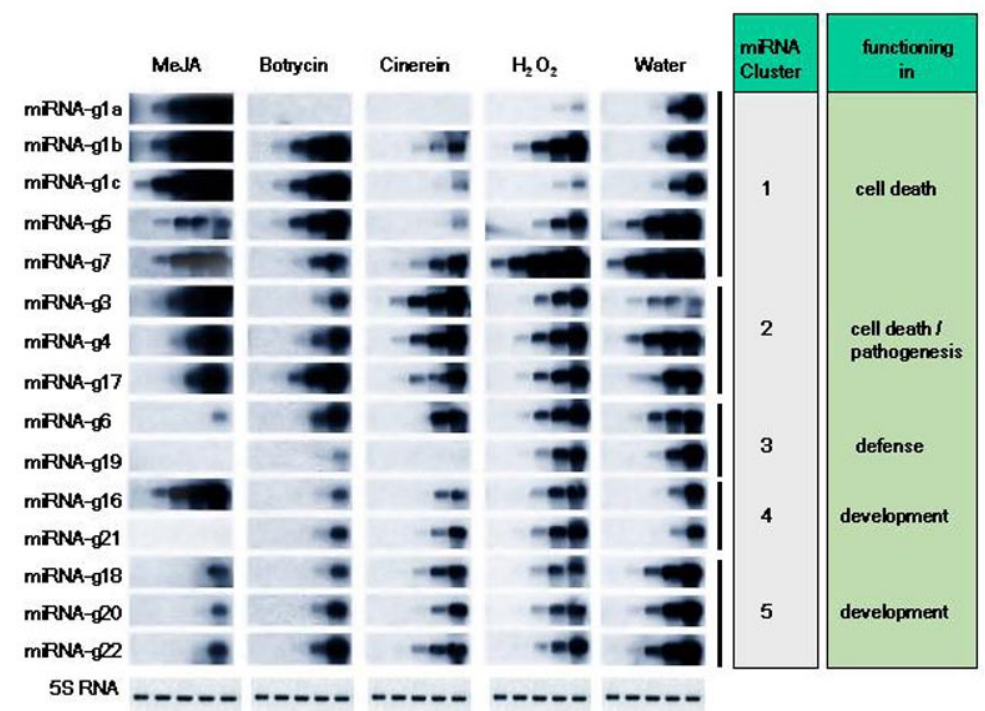

Figure 3. The PCR and corresponding Northern blot analysis of the overall expression profiles of 5 grapevine miRNA clusters (represented by 15 randomly selected miRNAs) after the pre-treatment of cell suspensions with the indicated apoptosis activators. The 5S RNA represents a gel loading control 
2C illustrates miRNAs that were expressed between different treatments compared with water-treated control sample. When the activator-specific miRNA expression patterns were examined, different types of patterns could be seen. For example, as revealed using Scatter plots, there was a very similar pattern of miRNA expression stimulated either with the MeJA or cinerein. A distinct miRNA expression pattern was observed for botrycin-treated cells.

To provide independent experimental support for the activator-stimulated expression of specific miRNA subsets, we randomly selected 15 grapevine miRNAs for RNA gel blot analysis using the same RNA samples used for microarray profiling. The RNA gel blot and PCR analyses revealed that all five clusters of grapevine miRNAs are differentially expressed in cell suspensions treated either with $50 \mu \mathrm{M}$ MeJA or the other elicitors like botrycin, cinerein and/or $\mathrm{H}_{2} \mathrm{O}_{2}$ (Figure 3). Moreover, there is a clear demonstration that miRNA cluster 1, directly involved in the regulation of apoptosis, was strongly expressed by MeJA and to a lesser extent by botrycin, cinerein and $\mathrm{H}_{2} \mathrm{O}_{2}$. In addition, the cluster 2 was relatively strongly expressed by either apoptosis activators. On the other hand, a limited expression of both developmentally regulated cluster, i.e. 4 and 5 was observed after pre-treatment of cell suspension by MeJA, botrycin and cinerein, and was stimulated by peroxide or in control cells. Defense-related cluster 3 of grapevine miRNAs was substantially induced by $50 \mu \mathrm{M}$ MeJA, surprisingly not by both elicitors isolated from a fungal necrotroph Botrytis cinerea Pers. et Fries (Figure 3).

Finally, we used a BLASTn search method to predict grapevine miRNA homologues. We found that a majority of these miRNAs were predicted to target stress/defense-related genes of plants. Of the $22 \mathrm{Vi}$ tis vinifera miRNAs, 11 have sequence conservation in Arabidopsis thaliana but exhibited species-specific developmental and/or stress/defense-related expression patterns. Ten of the miRNAs are highly conserved in other plant species, suggesting that even conserved miRNAs may have different regulatory roles in various species.

Due to the limited number of protein-coding sequences available for grapevine, we used BLASTn searches against the protein-coding databases of other plant species and BLASTn searches against the grapevine EST (expression sequences tags) database. By such approach, in addition to miRNAs, we identified 102 other novel endogenous small RNAs in Vitis, indicating that a large number of miRNAs and other small regulatory RNAs are encoded by the Vitis vinifera genome.

\section{CONCLUSIONS}

Our goal was to identify specific miRNAs from grapevine that could be involved in the execution and regulation of apoptosis. Results obtained here revealed novel insights into the activator-specific miRNA expression patterns of an extensive repertoire of genes expressed in grapevine cultivated suspension cells.

This work also establishes an extensive catalogue of miRNA expression patterns for future investigations aimed at the dissection of the transcriptional regulatory hierarchies that govern stress, developmental and tissue-specific expression patterns associated with tissue differentiation.

Finally, these results also confirmed that pre-treatment of grapevine cells with respective apoptosis activators has a profound effect on miRNA expression patterns particularly associated with the oncoming cell death.

Acknowledgement. This research work has been supported by a grant of the Slovak Ministry of Agriculture, contract No. 375/2010-510-K.

\section{REFERENCES}

ALTSCHUL, S.F. - MADDEN, T.L. - SCHAFFER, A.A. - ZHANG, J. - ZHANG, Z. - MILLER, W. - LIPMAN, D.J. 1997. Gapped BLAST and PSI-BLAST: A new generation of protein database search programs. In Nucleic Acids Research, vol. 25, 1997, no. 17, pp. 3389-3402, DOI: $10.1093 / \mathrm{nar} / 25.17 .3389$.

BRENNECKE, J. - MALONE, C.D. - ARAVIN, A.A. - SACHIDANANDAM, R. - STARK, A. - HANNON, G.J. 2008. An epigenetic role for maternally inherited piRNAs in transposon silencing. In Science, vol. 322, 2008, no. 5906, pp. 1387-1392 DOI: 10.1126/science.1165171.

CHICHKOVA, N.V. - KIM, S.H. - TITOVA, E.S. - KAKLUM, M. - MOROZOV, V.S. - RUBTSOV, Y.P. - KALININA, N.O. - TALIANSKY, M.E. - VARTAPETIAN, A. B. 2004. A plant caspase-like protease activated during the hypersensitive response. In Plant Cell, vol. 16, 2004, no. 1, pp. 157-171, DOI: $10.1105 /$ tpc.017889.

DING, Z.Y. - WANG, Y.H. - LUO, Z.K. - LEE, H.F. - 
HWANG, J. - CHIEN, C.T. - HUANG, M.L. 2011. Glial cell adhesive molecule unzipped mediates axon guidance in Drosophila. In Developmental Dynamics, vol. 240, 2011, no. 1, pp. 122-134.

EISEN, M. - SPELLMAN, P. - BROWN, P. - BOTSTEIN, D. 1998. Cluster analysis and display of genome-wide expression patterns. In Proceedings of the National Academy of Sciences of the United States of America, vol. 95, 1998, no. 95, pp. 14863-68.

HARA-NISHIMURA, I. - HATSUGAI, N. - NAKAUNE, S. - KUROYANAGI, M. - NISHIMURA, M. 2005. Vacuolar processing enzyme: an executor of plant cell death. In Current Opinion in Plant Biology, vol. 8, 2005, no. 4. pp. 404-408, DOI:10.1016/j.pbi.2005.05.016.

HATSUGAI, N. - KUROYANAGI, M. - YAMADA, K. MESHI, T.- TSUDA. S. - KONDO, M. - NISHIMURA, M. - HARA-NISHIMURA, I. 2004. A plant vacuolar protease, VPE, mediates virus-induced hypersensitive cell death. In Science, vol. 305,2004 , no. 5685, pp. 855-858, DOI: 10.1126/science. 1099859 .

HEDENFALK, I. - DUGGAN, D. - CHEN, Y. - RADMACHER, M. - BITTNER, M. - SIMON, R. - MELTZER, P. - GUSTERSON, B. - ESTELlER, M. - RAFFELD, M. ET AL. 2001. Gene-expression pro les in hereditary breast cancer. In The New England Journal of Medicine, vol. 344, 2001, pp. 539-548.

JONES-RHOADES, M.W. - BARTEL, D.P. 2004. Computational identification of plant microRNAs and their targets, including a stress-induced miRNA. In Molecular Cell, vol. 14, 2004, no. 6, pp. 787-799.

LACOMME, C. - SANTA CRUZ, S. 1999. Bax-induced cell death in tobacco is similar to the hypersensitive response. In Proceedings of the National Academy of Sciences of the United States of America, vol. 96, 1999, no. 14, pp. 79567961, DOI:10.1073/pnas.96.14.7956.

LANG, Q. - ZHOU, X.- ZHANG, X. - DRABEK, R. - ZUO, Z. - REN, Y. - LI, T. - CHEN, J. - GAO, X. 2011. Microarray-based identification of tomato microRNAs and time course analysis of their response to Cucumber mosaic virus infection. In Zhejiang University Press, vol. 12, 2011, no. 2, pp. 116-125, DOI:10.1631/jzus.B1000278.

LI, B. - QIN, Y. - DUAN, H. - YIN, W. - XIA, X. 2011. Genome-wide characterization of new and drought stress responsive microRNAs in Populus euphractica. In Journal of Experimental Botany, vol. 62, 2011, no. 11, pp. 37653779(15), DOI: dx.doi.org/10.1093/jxb/err051.

MERCHAN, F. - BOUALEM, A. - CRESPI, M. - FRUGIER, F. 2009. Plant polycistronic precursors containing non-homologous microRNAs target transcripts encoding functionally related proteins. In Genome Biology, vol. 10, 2009, no. 136 , pp. 136, DOI:10.1186/gb-2009-10-12-r136.

NAQVI, A.R. - HAQ, Q.M.R. - MUKHERJEE, S.K. 2011. MicroRNA profiling of tomato leaf curl new delhi virus (tolcndv) infected tomato leaves indicates that deregulation of mir159/319 and mir172 might be linked with leaf curl disease. In Virology Journal, vol. 7, 2011, pp. 281, DOI: $10.1186 / 1743-422 X-7-281$.

REPKA, V. 2002. Evidence for the involment of cysteine proteases in the regulation of methyl jasmotate-induced cell death in grapevine. In Vitis, vol. 41, 2002, no. 3, pp. 115121.
REPKA, V. - BAUMGARTNEROVÁ, I. 2008. Grapevine habituation: Understanding of factors that contribute to neoplastic transformation and somaclonal variation. In Acta Agronomica Hungarica, vol. 56, 2008, no. 4, pp. 339-409, DOI:10.1556/AAgr.56.2008.4.4

REPKA, V. - KUBÍKOVÁ, J. - FISHEROVÁ, I. 2000. Immunodetection of PR-1-like proteins in grapevine leaves infected with Oidium tuckerii and in elicited suspension cell cultures. In Vitis, vol. 39, 2000, no. 3, pp. 123-127.

REPKA, V. - FISHEROVÁ, I.- ŠILHÁKOVÁ, K. 2001. Biological activity of the elicitor released from mycelium of a grapevine isolate of the necrotrophic fungus Botrytis cinerea. In Vitis, vol. 40, 2001, no. 4, pp. 205-212.

REPKA, V. - FISHEROVÁ, I. - ŠILHÁROVÁ, K. 2004. Methyl jasmonate is a potent elicitor of multiple defense responses in grapevine leaves and cell-suspension cultures. In Biologia Plantarum, vol. 48, 2004, no. 2, pp. 273-283, DOI: 10.1023/B:BIOP.0000033456.27521.e5.

TAKAHASHI, M. - RHODES, D.R. - FURGE, K.A. KANAYAMA, H.- KAWAGA, S. - HAAB, B.B.- TEH, B.T. 2001. Gene expression profiling of clear cell renal cell carcinoma: gene idenification and prognostic classification. In Proceedings of the National Academy of Sciences of the United States of America, vol. 98, 2001, no. 17, pp. 9754-9759, DOI: 10.1073/pnas.171209998.

TALMOR-NEIMAN, M.- STAV, R.- FRANK, W.- VOSS, B.- ARAZI, T. 2006. Novel micro-RNAs and intermediates of micro-RNA biogenesis from moss. In Plant Journal, vol. 47, 2006, no. 1, pp. 25-37. DOI:10.1111/j.1365313X.2006.02768.x.

TANG, Y.C. - WILLIAMS, B.R. - SIEGEL, J.J. - AMON, A. 2011. Identification of aneuploidy- selective antiproliferation compounds. In Cell, vol. 144, 2011, no. 4, pp. $499-512$.

ZHA, H. - AIME-SEMPE, C. - SATO, T. - REED, J. C. 1996. Proapoptotic protein Bax heterodimerizes with Bcl-2 and homodimerizes with Bax via a novel domain (BH3) distinct from $\mathrm{BH} 1$ and $\mathrm{BH} 2$. In The Journal of Biological Chemistry, vol. 271. 1996, pp. 7440-7444, DOI: 10.1074/ jbc.271.13.7440.

ZHANG, B. - WANG, Q. - WANG, K. - PAN, X. - LIU, F. - GUO, T. - COBB, G.P. - ANDERSON, T.A. 2007. Identification of cotton microRNAs and their targets. In Gene, vol. 397, 2007, no. 1, pp. 26-37.

ZHANG, B. - PAN, X. - STELLWAG, E.J. 2008. Identification of soybean microRNAs and their targets. In Planta, vol. 229, 2008, no. 1, pp. 161-82.

Internet sources:

http://rana.lbl.gov/

Received: July, $4^{\text {th }}, 2011$ 